\title{
Effects of clay after a grain challenge on milk composition and on ruminal, blood, and fecal $\mathrm{pH}$ in Holstein cows
}

\author{
S. A. Sulzberger, ${ }^{*}$ C. C. Kalebich, ${ }^{*}$ S. Melnichenko,† and F. C. Cardoso*1 \\ *Department of Animal Sciences, University of Illinois, Urbana 61801 \\ †United Minerals Group, Kiev, Ukraine 04053
}

\begin{abstract}
Oral supplementation of clay has been reported to function as buffer in dairy cows. However, its effects on rumen, blood, and fecal $\mathrm{pH}$ have varied among studies. Our objective was to determine the effects of 3 concentrations of dietary clay supplementation after a grain challenge. Ten multiparous rumen-cannulated Holstein cows [body weight $($ mean \pm standard deviation $)=648$ $\pm 12 \mathrm{~kg}$ ] with $142 \pm 130$ (60 to 502 ) days in milk were assigned to 1 of 5 treatments in a replicated $5 \times$ 5 Latin square design balanced to measure carryover effects. Periods $(21 \mathrm{~d})$ were divided into an adaptation phase (d 1 to 18, with regular total mixed ration fed ad libitum) and a measurement phase (d 19 to 21). Feed was restricted on d 18 to $75 \%$ of the average of the total mixed ration fed from d 15 to 17 (dry matter basis), and on d 19 cows received a grain challenge. The challenge consisted of $20 \%$ finely ground wheat administered into the rumen via a rumen cannula, based on the average dry matter intake obtained on d 15 to 17 . Treatments were POS (no clay plus a grain challenge), 3 different concentrations of clay $(0.5,1$, or $2 \%$ of dietary dry matter intake), and control (C; no clay and no grain challenge). Statistical analysis was performed using the MIXED procedure of SAS (SAS Institute Inc., Cary, NC). Contrasts 1 (POS vs. C) and 2 (POS vs. the average of $0.5,1$, or $2 \%$ ) were compared, along with linear and quadratic treatment effects. Rumen, fecal, and blood $\mathrm{pH}$, along with blood metabolites, were measured at $0,4,8,12,16,20,24,36$, and $48 \mathrm{~h}$ relative to the grain challenge. Cows fed POS had lower rumen $\mathrm{pH}[$ (mean \pm standard error) $6.03 \pm 0.06]$ than cows fed C $(6.20 \pm 0.06)$. Cow fed POS had lower fecal $\mathrm{pH}(6.14 \pm 0.04)$ than cows fed C $(6.38 \pm 0.04)$. We observed a linear treatment effect for rumen $\mathrm{pH}$ and fecal pH. Fecal pH $(6.22 \pm 0.04)$ was higher for cows fed clay (contrast 2) then for cows fed POS $(6.14 \pm 0.04)$.
\end{abstract}

Received February 13, 2016.

Accepted June 28, 2016.

${ }^{1}$ Corresponding author: cardoso2@illinois.edu
We also observed a treatment difference (contrast 2) for negative incremental area under the curve, $\mathrm{pH}$ below $5.6 \times \mathrm{h} / \mathrm{d},(0.5 \%$ clay $=7.93 \pm 0.83,1 \%$ clay $=8.56 \pm$ 0.83 , and $2 \%$ clay $=7.79 \pm 0.83)$ compared with POS $(11.0 \pm 0.83)$. Cows fed clay tended to have higher milk yield $(0.5 \%$ clay $=28.8 \pm 3.4 \mathrm{~kg}, 1 \%$ clay $=30.2 \pm 3.4$ $\mathrm{kg}$, and $2 \%$ clay $=29.1 \pm 3.4 \mathrm{~kg}$, contrast 2$)$, and had higher $3.5 \%$ fat-corrected milk $(0.5 \%$ clay $=29.9 \pm 3.5$ $\mathrm{kg}, 1 \%$ clay $=34.1 \pm 3.5 \mathrm{~kg}$, and $2 \%$ clay $=33.1 \pm$ $3.4 \mathrm{~kg})$, and higher energy-corrected milk $(0.5 \%$ clay $=$ $29.1 \pm 3.3 \mathrm{~kg}, 1 \%$ clay $=32.8 \pm 3.4 \mathrm{~kg}$, and $2 \%$ clay $=$ $31.6 \pm 3.3 \mathrm{~kg})$ than cows fed POS $(27.7 \pm 3.4 \mathrm{~kg}, 28.0$ $\pm 3.4 \mathrm{~kg}, 27.7 \pm 3.3 \mathrm{~kg}$, respectively). In conclusion, cows fed clay had higher rumen $\mathrm{pH}$, energy-corrected milk, fat-corrected milk, and a trend for milk yield than cows fed POS.

Key words: buffer, clay, rumen $\mathrm{pH}$, grain challenge

\section{INTRODUCTION}

Dietary ingredients in dairy cow diets affect animal efficiency and health. To produce milk at maximum efficiency, concentrates are required as a feed choice, but a high inclusion of concentrate in the TMR has gained popularity (Eastridge, 2006). Increasing concentrateto-forage ratios and more elaborate grain processing in lactating dairy cow diets have been associated with higher milk production (Khorasani and Kennelly, 2001; Yang et al., 2001). However, too much concentrate can challenge the cow's natural buffering capacity and leave the rumen susceptible to drastic drops in $\mathrm{pH}$ levels (Shaver et al., 2000). Knowing the diurnal rhythm of rumen $\mathrm{pH}$ is crucial to understanding when a cow confronts SARA (Enemark, 2008). The minimum rumen $\mathrm{pH}$ fluctuates from 5.4 to 6.6, making it difficult to distinguish what is truly SARA (Duffield et al., 2004; Krause and Oetzel, 2006). Gozho et al. (2005) have defined SARA as when rumen $\mathrm{pH}$ is between 5.2 and 5.6 for at least $3 \mathrm{~h} / \mathrm{d}$. Cows facing SARA may experience symptoms such as decreased DMI and milk production, altered milk composition, diarrhea, and laminitis (Duffield, et al., 2004; Gozho et al., 2005; 
Krause and Oetzel, 2006; Plaizier et al., 2008). Even though SARA is difficult to diagnose, it is estimated to be prevalent in 19 to $26 \%$ of early- and mid-lactation dairy cattle (Enemark, 2008; Plaizier et al., 2008). Changes in rumen $\mathrm{pH}$ bring about changes in microbial populations that may lead to a decrease in milk fat percentages (Krause and Oetzel, 2005; Weimer et al., 2010). Additionally, the feces of cows with SARA have a lower DM content, longer particles, whole grains, a sweet-sour smell, and appear to be brighter, yellowish, and liquid (Oetzel, 2000; Kleen et al., 2003; Li et al., 2012). It is thought that these alterations are caused by postruminal fermentation in the intestines due to a massive outflow of fermentable carbohydrates from the rumen (Oetzel, 2000; Plaizier et al., 2008). Mixing feed additives (buffers) into the diet of dairy cows has been proven to alleviate the adverse health effects of SARA (Ghorbani et al., 1989; Shaver et al., 2000; Enemark, 2008; Cruywagen et al., 2015). Buffers have been used primarily to maintain rumen environments with a $\mathrm{pH}$ $>5.0$ and $<7.0$ (Shaver et al., 2000).

Clays are the products of silicate rocks that have been subjected to weathering processes for thousands of years (Buckman and Brady, 1969). Many types of clays have been used in diets as buffers; "silicate" is a specific term to describe clay. The main classification is phyllosilicates, which consists of many subcategories: kaolinite, smectites, chlorites, and micas (Adamis and Williams, 2005). Each term describes the chemical composition: for example, kaolins are usually composed of quartz and mica and have been used to treat digestive problems, and bentonites have been used as enterosorbents (Trckova et al., 2004). Bentonites consist primarily of a mineral called montmorillonite, which has an articulated layer structure with a net negative charge, balanced by cations within the interlayer space. Montmorillonite has an attraction for mono- and divalent ions that bind proteins and nitrogenous compounds to bypass the rumen (Wester, 2002; Trckova, et al., 2004; Adamis and Williams, 2005). Adding bentonite to corn before ensiling at 0.5 and $1.0 \%$ of the wet weight significantly increased the $\mathrm{pH}$ of the corn silage (Everson et al., 1971).

Understanding how rumen, blood, and fecal $\mathrm{pH}$ are affected by clay after a grain challenge in Holstein cows and its effect on production parameters deserves attention. The objectives of this experiment were (1) to determine the effects of a commercially available clay product after a grain challenge on ruminal, blood, and fecal $\mathrm{pH}$, as well as on milk composition, in midlactation Holstein cows; and (2) to determine the most appropriate clay concentration to be used in the diet of lactating dairy cows.

\section{MATERIALS AND METHODS}

\section{Animals and Housing}

All experimental procedures were approved by the University of Illinois (Urbana-Champaign) Institutional Animal Care and Use Committee. The experimental period was September to December 2014. Cows were housed in tie stalls with sand bedding and ad libitum water and feed access. Mineral salt blocks were available at all times in the alleys from the tie stalls to the milking parlor (Big 6 Mineral Salt; North American Salt Company, Overland Park, KS). The diet (TMR) was formulated according to NRC (2001) recommendations.

\section{Experimental Design and Grain Challenge Procedure}

A total of 10 multiparous rumen-cannulated Holstein cows $[\mathrm{BW}($ mean $\pm \mathrm{SD})=648 \pm 12 \mathrm{~kg}]$ with $142 \pm$ 130 (60-502) DIM were assigned to 1 of 5 treatments in a replicated $5 \times 5$ Latin square design balanced to measure carryover effects. Treatments were arranged so that carryover effects could be evaluated. Periods (21 d) were divided into an adaptation phase (d 1 to 18, with regular TMR fed ad libitum) and a measurement phase (d 19 to 21). Day 18 had restricted feeding (cows were offered $75 \%$ of the average of the TMR fed on $\mathrm{d}$ 15 to 17 , DM basis), and on d 19 a grain challenge occurred. A schematic representation of the experimental phase is shown in Figure 1. The grain challenge was similar to the one used for SARA induction proposed by Kmicikewycz and Heinrichs (2014). A grain challenge consisted of finely ground wheat administered via rumen cannula at a level of $20 \%$ of the average DMI obtained on d 15 to 17 . Treatments were no clay plus a grain challenge (POS), 3 different concentrations of clay $(0.5,1$, or $2 \%$ of dietary DMI), and a no clay and no grain challenge (control, $\mathbf{C}$ ).

The clay used in this experiment was analyzed by inductively coupled plasma mass spectrometry and had the following mineral content (percentage of DM): magnesium 7.2 , silicon 6.3 , aluminum $>5$, iron 6.9 , potassium 0.5 , and manganese $<0.1$. Ion chromatography was used to report the presence of other chemical functional groups. The clay's ionic composition $(\mathrm{mg} /$ $\mathrm{kg}$ ) was sulfate 124 , chloride 113 , carbonate 641 , nitrate 97, and phosphate 2 (Avomeen Analytical Sevices, Ann Arbor, MI).

All cows were fed the same TMR throughout the trial, and were fed once daily at $1400 \mathrm{~h}$. The daily clay allocation was weighed every day to correlate to kilograms of TMR offered, and equal portions were offered 
Table 1. Ingredient composition of the lactation diet fed to cows in positive control with no clay (POS), $0.5,1$, or $2 \%$ clay, or negative control (C) treatments throughout the experimental period

\begin{tabular}{lc}
\hline Ingredient & \% of DM \\
\hline Alfalfa hay & 8.20 \\
Corn silage & 33.6 \\
Alfalfa silage & 7.20 \\
Wet brewers grain & 7.49 \\
Dry ground corn grain & 21.55 \\
Soybean meal, 48\% & 3.25 \\
Expeller soybean meal ${ }^{1}$ & 3.30 \\
Soy hulls & 10.42 \\
Limestone & 0.13 \\
Dicalcium phosphate & 0.35 \\
Bypass fat & \\
Biotin & 1.87 \\
Molasses, sugar beet & 0.34 \\
Salt (plain) & 2.05 \\
Mineral and vitamin mix $^{3}$ & 0.04 \\
\hline
\end{tabular}

${ }^{1}$ SoyPlus (West Central, Ralston, IA).

${ }^{2}$ Energy Booster 100 (Milk Specialties Global, Paris, IL).

${ }^{3}$ Formulated with $5 \% \mathrm{Mg}, 10 \% \mathrm{~S}, 7.5 \% \mathrm{~K}, 2.0 \% \mathrm{Fe}, 3.0 \% \mathrm{Zn}, 3.0 \% \mathrm{Mn}$, $5,000 \mathrm{mg} / \mathrm{kg}$ of $\mathrm{Cu}, 250 \mathrm{mg} / \mathrm{kg}$ of I, $40 \mathrm{mg} / \mathrm{kg}$ of Co, $150 \mathrm{mg} / \mathrm{kg}$ of Se, $2,200 \mathrm{kIU} / \mathrm{kg}$ of vitamin $\mathrm{A}, 660 \mathrm{kIU} / \mathrm{kg}$ of vitamin $\mathrm{D}_{3}$, and $7,700 \mathrm{IU} /$ $\mathrm{kg}$ of vitamin $\mathrm{E}$.

at 0600 and $1400 \mathrm{~h}$. Each portion was mixed with 0.5 $\mathrm{kg}$ of ground corn and top dressed on the TMR. Cows in the $\mathrm{C}$ and POS treatment groups were given a top dress consisting of $0.5 \mathrm{~kg}$ of ground corn only.

\section{Data Collection and Sampling Procedures}

Samples of feed ingredients and TMR (Tables 1 and 2) were obtained on the first day of each week and analyzed for DM (AOAC International, 1995a) by drying for $24 \mathrm{~h}$ in a forced-air oven at $110^{\circ} \mathrm{C}$. Diet composition was adjusted weekly for changes in DM content. The TMR offered and refused from each cow was recorded to determine intake based on weekly DM analyses. Daily DMI was used to calculate daily clay allocation. Samples of TMR delivered to each cow, $\mathrm{n}$ $=10)$ were taken on d 15 of each period and stored at $-20^{\circ} \mathrm{C}$ until analyzed. Composite samples (3 per period) were analyzed for contents of DM, CP, ADF, NDF, lignin, starch, fat, ash, $\mathrm{Ca}, \mathrm{P}, \mathrm{Mg}, \mathrm{K}, \mathrm{Na}, \mathrm{Fe}, \mathrm{Zn}, \mathrm{Cu}$, $\mathrm{Mn}$, Mo, and S using wet chemistry methods (Dairy One, Ithaca, NY; (http://dairyone.com/wp-content/ uploads/2014/02/Forage-Lab-Analytical-ProceduresListing-Alphabetical-July-2015.pdf). The value for $\mathrm{NE}_{\mathrm{L}}$ was provided by the laboratory and calculated based on NRC (2001). The physical characteristic of the TMR, based on the Penn State Particle Separator (Kononoff et al., 2003), was performed on the first day of each week.

Cows were milked 3 times daily at 0400, 1200, and 2200 h. Milk weights were recorded at every milking, and samples were obtained from $\mathrm{d} 15$ at each of the
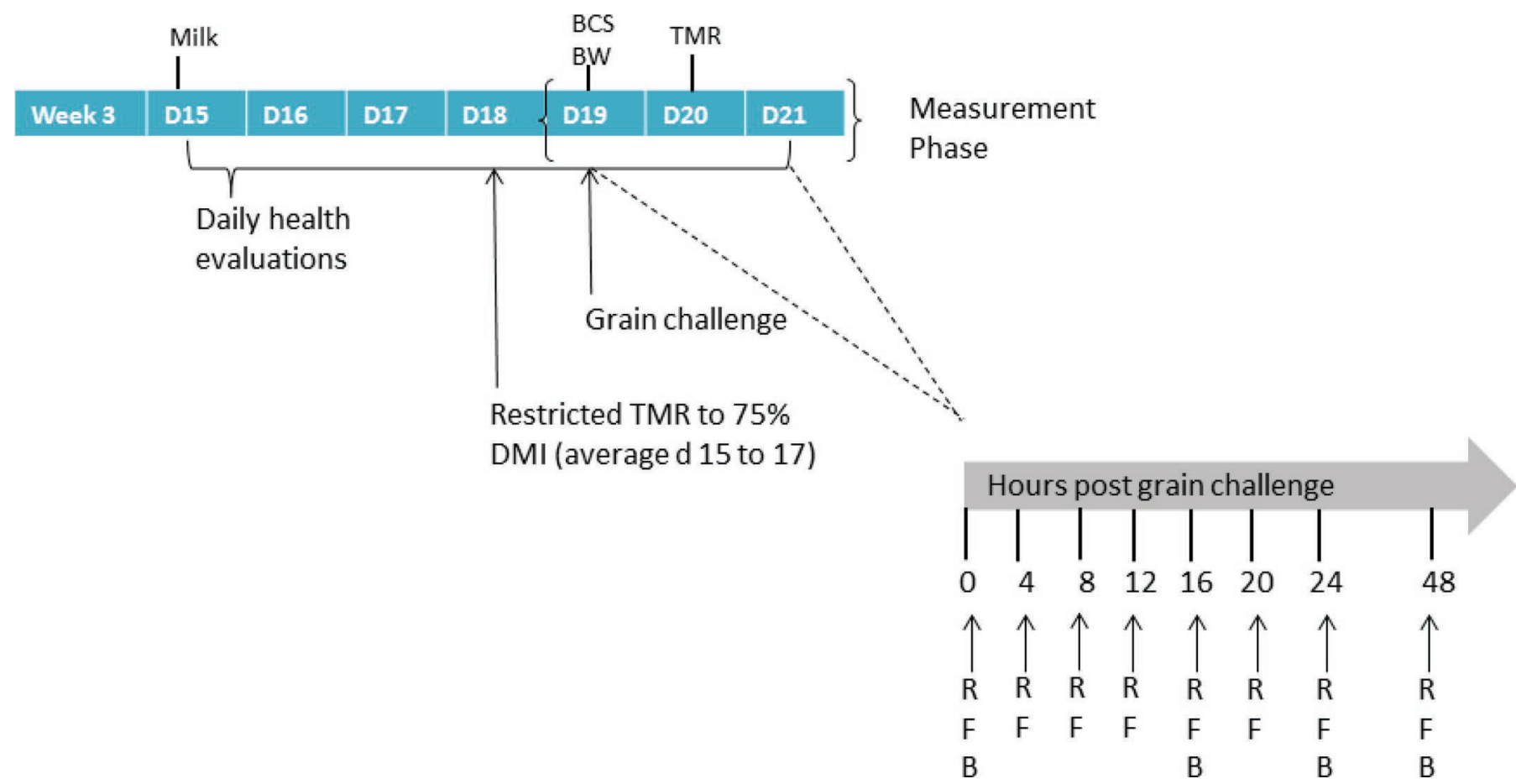

Figure 1. Schematic design of each experimental period and its sampling time points (days, D, 15 to 21). Milk = composite milk sample, R = rumen sample, $\mathrm{F}=$ fecal sample, $\mathrm{B}=$ blood sample. Similar diets were fed the entire period before the grain challenge. Color version available online. 
corresponding milkings. A preservative was added to each milk sample, and samples were refrigerated for 3 d (800 Broad Spectrum Microtabs II; D\&F Control Systems Inc., San Ramon, CA). The preserved samples were composited in proportion to milk yield at each sampling and sent to a commercial laboratory (Dairy Lab Services, Dubuque, IA) to be analyzed for fat, protein, lactose, urea N, total solids, and SCC using mid-infrared procedures (AOAC International, 1995b).

Health evaluations were conducted daily during the last week of each period for the duration of the challenge. Visual assessments were conducted to monitor general appearance and fecal score. Rectal temperature was measured using a GLA M700 thermometer (GLA Agricultural Electronics, San Luis Obispo, CA). Respiration rate was recorded by watching the cow breathe for $15 \mathrm{~s}$, and heart rate was measured using a stethoscope for $15 \mathrm{~s}$. General appearance was scored using a method similar to Krause et al. (2009): $4=$ bright and alert; $3=$ depressed; $2=$ reluctant to rise; $1=$ down cow, will not get up. Fecal scores were allocated on a scale of 1 to 4 according to Krause et al. (2009): $1=$ runny: liquid consistency, splatters on impact, spreads readily; 2 = loose: may pile slightly and spreads and splatters moderately on impact and setting; $3=$ soft: piles up but spreads slightly on impact and settling;
$4=$ dry: hard, dry appearance, original form not distorted on impact and settling. Body temperature was considered elevated if $>39.4^{\circ} \mathrm{C}$; heart rate was considered elevated if $>100$ beats/min; respiratory rate was considered abnormal if $>40$ breaths/min; general appearance was considered abnormal if $\leq 2$; and fecal score was considered abnormal if $\leq 2$ (Ireland-Perry and Stallings, 1993; Krause and Oetzel, 2005).

Body weight was measured (CW-11 digital scale; Ohaus, Newark, NJ) and BCS was assigned in quarterunit increments for each cow weekly (Ferguson et al., 1994). More than 1 person assigned a BCS independently at each time of scoring, and the average score was used for statistical analysis. Cows were fitted with an activity logger (Hobo Pendant G Acceleration Data Logger; Onset Computer Corp., Pocasset, MA) positioned laterally on the distal portion of the left hind leg. The activity logger was attached to the leg using vet wrap. Data points were set to record at $60 \mathrm{~s}$ intervals. Data collected were used to calculate total lying time, number of lying bouts (number times lying down/24 h), and duration of lying bouts (time from lying down to standing up), as well as standing time, standing bouts (number times stood/24 h), and duration of each standing bout (time from standing up to lying down).

Table 2. Mean chemical composition and associated standard deviations for diets fed to cows in positive control with no clay (POS), $0.5,1$, or $2 \%$ clay, and negative control $(\mathrm{C})$ treatments throughout the experimental period

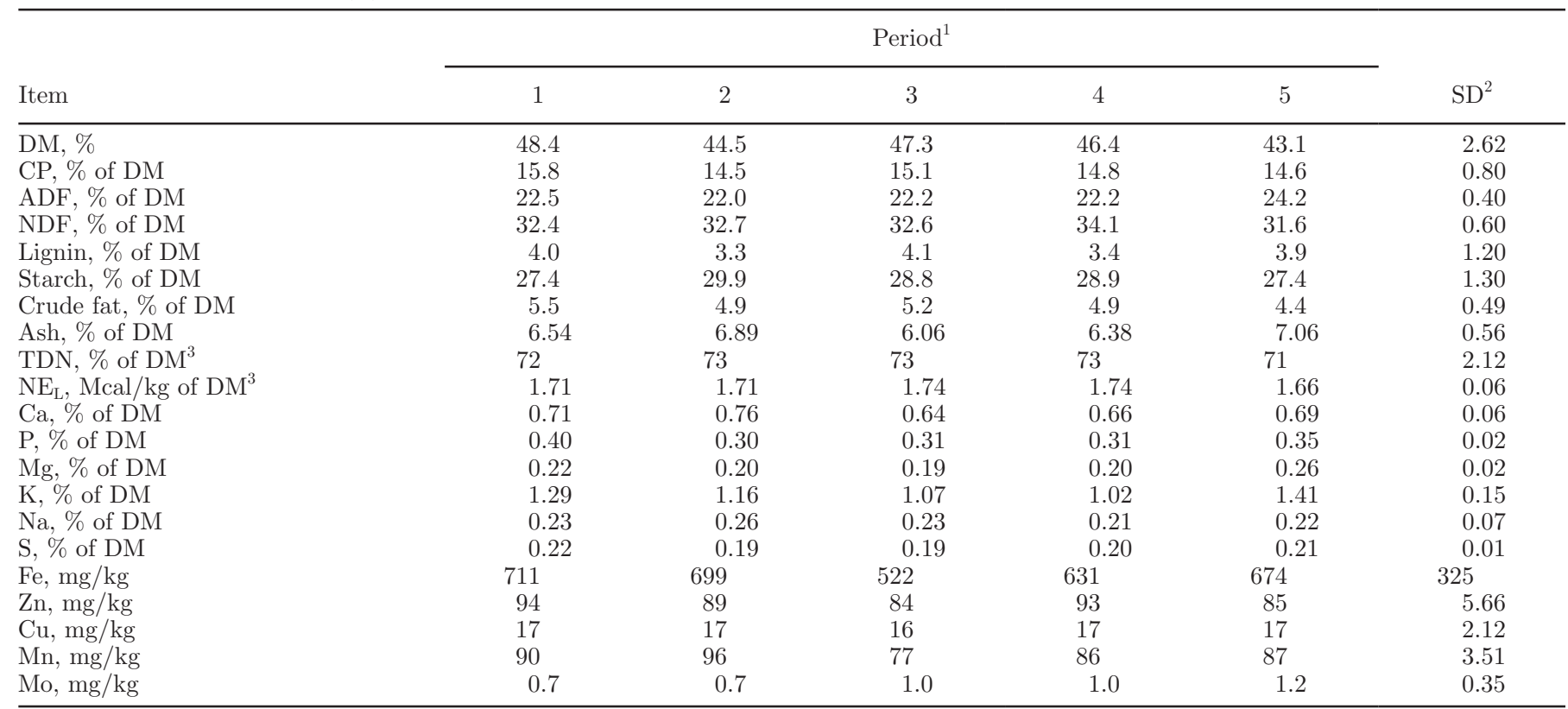

${ }^{1}$ Period $=3$ consecutive weeks. Cows were fed TMR ad libitum. Each cow was given a mixture of $500 \mathrm{~g}$ of ground corn and clay at $0,0.5,1$, or $2 \%$ of dietary DM. The clay was split into 2 top dress amounts and given immediately after feeding and again after $14 \mathrm{~h}$.

${ }^{2}$ Maximum within-period SD.

${ }^{3} \mathrm{NRC}(2001)$. 
Rumen fluid (500 mL) was extracted via rumen cannula by pumping a representative sample (ventral sac, cranial sac, and caudo-ventral blind sac) into a graduated cylinder using a siphon for immediate $\mathrm{pH}$ measurement with a portable pH meter (AP110, Fisher Scientific, Pittsburgh, PA). Samples were collected at $0,4,8,12,16,20,24,36$, and $48 \mathrm{~h}$ relative to the grain challenge (time point 0) on d 19 of each period. At the same time points, fecal samples (approximately 40 $\mathrm{g}$ wet weight) were collected from the rectum of each cow into plastic containers, and fecal $\mathrm{pH}$ was measured immediately after collection with the portable $\mathrm{pH}$ meter (AP110, Fisher Scientific). Blood samples were collected from the coccygeal vein or artery at $0,16,24$, and $48 \mathrm{~h}$ relative to the grain challenge. Blood samples were collected into tubes containing heparin sulfate and placed on ice. Heparin sulfate tubes were taken to the University of Illinois clinical pathology laboratory within 10 min of collection for blood gas analysis to measure $\mathrm{pH}$, partial pressure of $\mathrm{CO}_{2}\left(\mathrm{pCO}_{2}\right)$, partial pressure of $\mathrm{O}_{2}\left(\mathrm{pO}_{2}\right)$, base excess, $\mathrm{HCO}_{3}$, total $\mathrm{CO}_{2}\left(\mathrm{tCO}_{2}\right)$, $\mathrm{O}_{2}$ saturation, and lactate (photometric analysis performed according to the laboratory procedures on the AU680 Chemistry Analyzer, Beckman Coulter, Brea, $\mathrm{CA}$ ). Additional samples were collected into tubes (BD Vacutainer; BD and Co., Franklin Lakes, NJ) containing a clot activator for serum and dipotassium EDTA for plasma. Serum and plasma samples were obtained by centrifugation at $2,500 \times g$ for $15 \mathrm{~min}$ and stored at $-20^{\circ} \mathrm{C}$ until further analysis.

\section{Statistical Analyses}

Data were analyzed using the mixed model procedure of SAS (v 9.3; SAS Institute Inc., Cary, NC) to account for carryover effect using the following model:

$$
\mathrm{y}_{\mathrm{ijklm}}=\mu+\mathrm{S}_{\mathrm{i}}=\mathrm{A}_{(\mathrm{i}) \mathrm{j}}+\mathrm{P}_{(\mathrm{i}) \mathrm{k}}+\mathrm{T}_{1}+\mathrm{C}_{\mathrm{m}}+\mathrm{e}_{(\mathrm{ijk}) \mathrm{l}},
$$

where $\mathrm{y}_{\mathrm{ijk} k \mathrm{~m}}$ is the observation for dependent variables; $\mu$ is the general mean; $S_{i}$ is the fixed effect of the $i$ th treatment sequence; $\mathrm{A}_{(\mathrm{i}) \mathrm{j}}$ is the random effect of the $j$ th cow in the $i$ th sequence; $\mathrm{P}_{(\mathrm{i}) \mathrm{k}}$ is the fixed effect of the $k$ th period; $\mathrm{T}_{1}$ is the fixed effect of the $l$ th treatment; $\mathrm{C}_{\mathrm{m}}$ is the fixed carryover effect from the previous period $(\mathrm{C}=0$ if period $=1)$; and $\mathrm{e}_{(\mathrm{ijk}) \mathrm{l}}$ is the random error. If carryover effects were not detected, data were analyzed as a replicated Latin square using the following model:

$$
\begin{aligned}
\mathrm{y}_{\mathrm{ijk} k \mathrm{~m}}=\mu & +\mathrm{S}_{\mathrm{i}}=\mathrm{A}_{(\mathrm{i}) \mathrm{j}}+\mathrm{P}_{(\mathrm{i}) \mathrm{k}}+\mathrm{T}_{1}+\mathrm{D}_{\mathrm{m}} \\
& +\mathrm{T} \times \mathrm{D}_{\mathrm{lm}}+\mathrm{e}_{(\mathrm{ijk}) \mathrm{lm}},
\end{aligned}
$$

where $y_{i j k l m}$ was the observation for dependent variables; $\mu$ was the general mean; $S_{i}$ was the fixed effect of the $i$ th treatment sequence; $\mathrm{A}_{(\mathrm{i}) \mathrm{j}}$ was the random effect of the $j$ th cow in the $i$ th sequence; $\mathrm{P}_{(\mathrm{i}) \mathrm{k}}$ was the fixed effect of the $k$ th period; $\mathrm{T}_{1}$ was the fixed effect of the $l$ th treatment; $D_{m}$ was the fixed effect of repeated measurement, which was used as time point in $\mathrm{pH}$ and day in DMI analysis; $T \times D_{l m}$ was the interaction of treatment and repeated measurement (the interaction was removed if $P>0.3)$; and $\mathrm{e}_{(\mathrm{ijk}) \mathrm{l}}$ is the random error. The estimation method was restrictive maximum likelihood and the degrees of freedom method was Kenward-Rogers (Littell et al., 2002). Variables were subjected to 5 covariance structures: compound symmetry, autoregressive order 1 , autoregressive heterogeneous order 1 , unstructured, and Toeplitz. The covariance structure that yielded the lowest corrected Akaike information criterion was compound symmetry and was used in the model (Littell et al., 2002).

A $\log _{10}$ transformation was used for milk SCC, lactate, $\mathrm{pCO}_{2}$, and $\mathrm{tCO}_{2}$ for better homogeneity of the distribution of residuals. Means shown in tables and graphs for these variables were back-transformed. Orthogonal contrasts were tested using the CONTRAST statement in SAS: contrast 1 was POS (0\% clay) compared with C; contrast 2 was POS ( $0 \%$ clay) compared with the average of the 3 clay treatments $(0.5,1$, or $2 \%)$ and linear and quadratic effects of treatments POS (0), $0.5,1$, or $2 \%$. Values reported are least squares means and associated standard errors of the mean. Area under the curve was calculated based on the incremental area method (Cardoso et al., 2011), with pH 5.6 as the baseline. Residual distribution was evaluated for normality and homoscedasticity. A multivariable logistic mixed model (FREQ procedure) was used for the dichotomized variables (fecal score, general appearance, temperature, respiration, and heart rate). The chi-squared value was computed. Statistical significance was declared at $P \leq$ 0.05 and trends at $0.05<P \leq 0.10$.

\section{RESULTS}

\section{Diet Composition}

The ingredient composition of the diets is detailed in Table 1. Analyzed nutrients from the experimental diet are shown in Table 2. The physical characteristics of the TMR was (mean \pm SD) $4.8 \pm 1 \%$ on upper, $38.6 \pm$ $3 \%$ on middle, $40.7 \pm 3 \%$ on lower sieves, and $15.8 \pm$ $2 \%$ in the pan. Carryover effect was tested and was not present for any variable of interest $(P>0.45)$. 


\section{DMI and Lactation Performance}

Performance data are shown in Table 3. Cows fed POS had lower $(P=0.02)$ DMI than cows fed C. We observed no difference in DMI among cows fed clay $(0.5,1$, or $2 \%)$ compared with cows fed POS. Cows fed POS yielded less $(P=0.009)$ milk than cows fed C. Cows fed clay $(0.5,1$, or $2 \%)$ tended to yield more milk $(P=0.06)$ and had higher $3.5 \%$ FCM $(P=0.02)$ and $\operatorname{ECM}(P=0.01)$ than cows fed POS. Cows fed clay $(0.5,1$, or $2 \%)$ produced more $(P=0.05)$ milk fat yield when compared with cows in POS. We observed a positive linear treatment $(P=0.03)$ effect on milk fat yield and an increase in fat $(\mathrm{kg} / \mathrm{d} ; P=0.05)$ when cows were fed clay during a grain challenge. We observed a quadratic treatment effect $(P=0.03)$ for milk protein $(\mathrm{kg} / \mathrm{d})$, with cows fed $\mathrm{C}$ yielding more protein $(P<$ $0.01)$. Cows fed clay $(0.5,1$, or $2 \%)$ had a tendency $(P$ $=0.10)$ for a linear treatment effect for $3.5 \% \mathrm{FCM} /$ DMI, with clay $1 \%$ being numerically higher (for every $1 \mathrm{~kg}$ of DMI, $1.99 \mathrm{~kg}$ of $3.5 \%$ FCM milk was produced) than the others.

\section{Blood Gas and Rumen, Blood, and Fecal pH}

Table 4 and Figures 2, 3, and 4 show the results for blood gas and metabolites, and blood, rumen, and fecal $\mathrm{pH}$. Rumen $\mathrm{pH}$ was different $(P=0.003)$ for cows fed C compared with cows fed POS. Cows fed clay $(0.5,1$, or $2 \%)$ had higher $(P=0.02)$ rumen $\mathrm{pH}$ than cows fed POS. Time points differed $(P<0.0001)$ for rumen $\mathrm{pH}$, fecal $\mathrm{pH}$, base excess, and blood $\mathrm{HCO}_{3}$, as well as blood $\mathrm{pH}(P=0.001)$. We observed a positive linear treatment effect $(P=0.001)$ on rumen $\mathrm{pH}$ and a tendency for a positive linear treatment effect $(P=0.06)$ for fecal $\mathrm{pH}$. Nadir rumen $\mathrm{pH}$ tended to be lower $(P=0.06)$ for cows fed POS than cows fed C. Cows fed clay $(0.5,1$, or $2 \%)$ had higher $(P=0.03)$ nadir rumen $\mathrm{pH}$ than cows fed POS. Cows fed POS spent more time $(P=0.007)$ with rumen $\mathrm{pH}$ below 5.6 (are under the curve) than cows fed C. Cows fed clay $(0.5,1$, or $2 \%$ ) spent less time $(P=0.005)$ with rumen $\mathrm{pH}$ below 5.6 than cows fed POS. We observed a negative linear treatment $(P$ $=0.03$ ) effect for the time cows spent with rumen $\mathrm{pH}$ below 5.6. Fecal $\mathrm{pH}$ was different $(P<0.0001)$ between

Table 3. Least squares means and associated SEM for DMI, BW, BCS, and milk parameters response to a grain challenge for cows in positive control with no clay (POS), $0.5,1$, or $2 \%$ clay, and negative control (C)

\begin{tabular}{|c|c|c|c|c|c|c|c|c|c|c|}
\hline \multirow[b]{3}{*}{ Item } & \multicolumn{5}{|c|}{ Treatment $(\mathrm{Trt})^{1}$} & \multirow[b]{3}{*}{ SEM } & \multicolumn{4}{|c|}{$P$-value ${ }^{2}$} \\
\hline & \multirow[b]{2}{*}{ POS } & \multirow[b]{2}{*}{$0.5 \%$} & \multirow[b]{2}{*}{$1 \%$} & \multirow[b]{2}{*}{$2 \%$} & \multirow[b]{2}{*}{$\mathrm{C}$} & & \multicolumn{2}{|c|}{ Contrast } & \multicolumn{2}{|c|}{ Trt } \\
\hline & & & & & & & 1 & 2 & Linear & Quadratic \\
\hline$\overline{\mathrm{DMI}},{ }^{3} \mathrm{~kg} / \mathrm{d}$ & 16.97 & 17.96 & 16.63 & 17.52 & 19.00 & 1.14 & 0.02 & 0.55 & 0.81 & 0.84 \\
\hline $\mathrm{BW}, \mathrm{kg}$ & 643.9 & 648.4 & 650.7 & 648.2 & 652.1 & 12.2 & 0.44 & 0.54 & 0.71 & 0.58 \\
\hline $\mathrm{BCS}$ & 3.04 & 3.23 & 3.11 & 3.08 & 3.24 & 0.10 & $<0.01$ & 0.10 & 0.79 & 0.09 \\
\hline \multicolumn{11}{|l|}{ Milk yield } \\
\hline Milk yield kg/d & 27.72 & 28.77 & 30.20 & 29.08 & 30.58 & 3.4 & 0.009 & 0.06 & 0.18 & 0.06 \\
\hline $3.5 \% \mathrm{FCM}$ & 28.24 & 29.85 & 34.13 & 33.09 & 30.00 & 3.4 & 0.42 & 0.02 & 0.01 & 0.14 \\
\hline $\mathrm{ECM}$ & 27.71 & 29.05 & 32.82 & 31.56 & 29.63 & 3.3 & 0.27 & 0.01 & 0.01 & 0.09 \\
\hline \multicolumn{11}{|l|}{ Milk composition } \\
\hline Fat, $\%$ & 3.86 & 4.03 & 4.20 & 4.35 & 3.63 & 0.34 & 0.56 & 0.33 & 0.22 & 0.79 \\
\hline Fat, kg/d & 1.00 & 1.08 & 1.29 & 1.26 & 1.04 & 0.13 & 0.74 & 0.05 & 0.03 & 0.25 \\
\hline Protein, $\%$ & 3.01 & 3.00 & 2.99 & 2.92 & 3.05 & 0.09 & 0.49 & 0.42 & 0.10 & 0.62 \\
\hline Protein, kg/d & 0.83 & 0.85 & 0.89 & 0.84 & 0.91 & 0.10 & $<0.01$ & 0.16 & 0.73 & 0.03 \\
\hline Lactose, $\%$ & 4.66 & 4.55 & 4.67 & 4.47 & 4.46 & 0.11 & 0.04 & 0.24 & 0.09 & 0.44 \\
\hline Lactose, $\mathrm{kg} / \mathrm{d}$ & 1.30 & 1.32 & 1.43 & 1.31 & 1.36 & 0.16 & 0.27 & 0.26 & 0.84 & 0.03 \\
\hline MUN, mg/dL & 12.43 & 11.52 & 12.18 & 11.07 & 11.69 & 0.68 & 0.43 & 0.27 & 0.21 & 0.88 \\
\hline $\mathrm{SCC}, \log _{10}$ & 4.30 & 4.12 & 4.26 & 4.48 & 4.74 & 0.54 & 0.37 & 0.98 & 0.60 & 0.61 \\
\hline $3.5 \% \mathrm{FCM} / \mathrm{DMI}, \mathrm{kg} / \mathrm{kg}$ & 1.66 & 1.67 & 1.99 & 1.85 & 1.61 & 0.14 & 0.77 & 0.15 & 0.10 & 0.23 \\
\hline $\mathrm{ECM} / \mathrm{DMI}, \mathrm{kg} / \mathrm{kg}$ & 1.62 & 1.61 & 1.91 & 1.76 & 1.59 & 0.13 & 0.79 & 0.19 & 0.14 & 0.20 \\
\hline Milk/DMI, kg/kg & 1.63 & 1.57 & 1.78 & 1.62 & 1.63 & 0.14 & 0.91 & 0.64 & 0.71 & 0.13 \\
\hline
\end{tabular}

${ }^{1}$ Dietary treatments were positive control [POS, without clay $(0 \%)$ and with grain challenge], $0.5 \%$ clay $(0.5 \%$ of the dietary DMI as clay in a top dress), $1 \%$ clay ( $1 \%$ of the dietary DMI as clay in a top dress), $2 \%$ clay ( $2 \%$ of the dietary DMI as clay in a top dress), and negative control (C, without clay and no grain challenge). Top dress vehicle was $500 \mathrm{~g}$ of ground corn. Grain challenge $=20 \%$ of the average of the DMI of the last $3 \mathrm{~d}$ before the challenge as finely ground wheat.

${ }^{2}$ Contrasts: $1=\operatorname{POS}(0 \%)$ compared with C; $2=\operatorname{POS}(0 \%)$ compared with the average of the 3 treatments $(0.5,1$, or $2 \%)$. Linear and quadratic effects of treatments POS $(0 \%), 0.5,1$, and $2 \%$.

${ }^{3} \mathrm{TMR}$ was restricted to $75 \%$ of average DMI on d 18 of each period. These DMI do not include feed received as part of a grain challenge. 


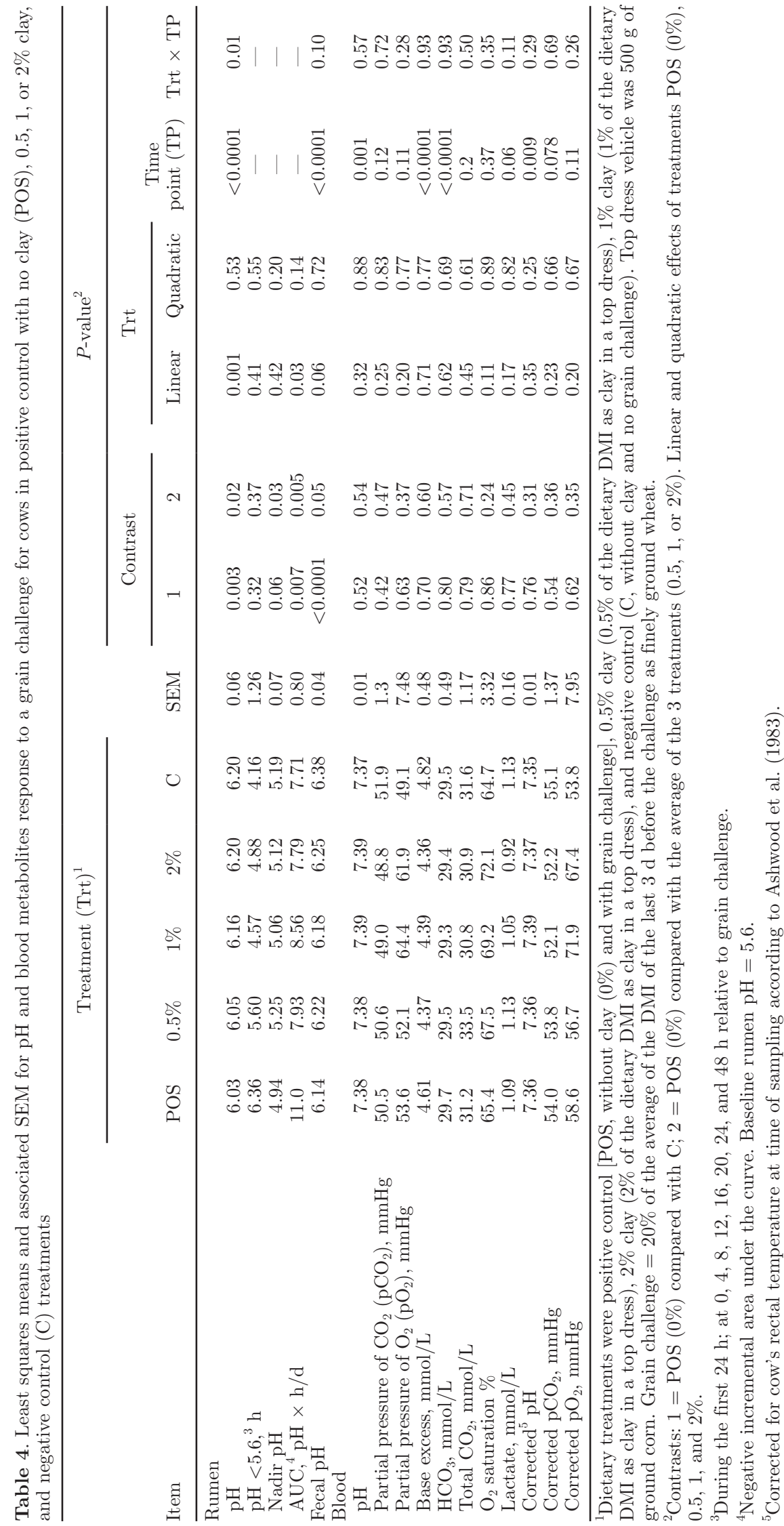




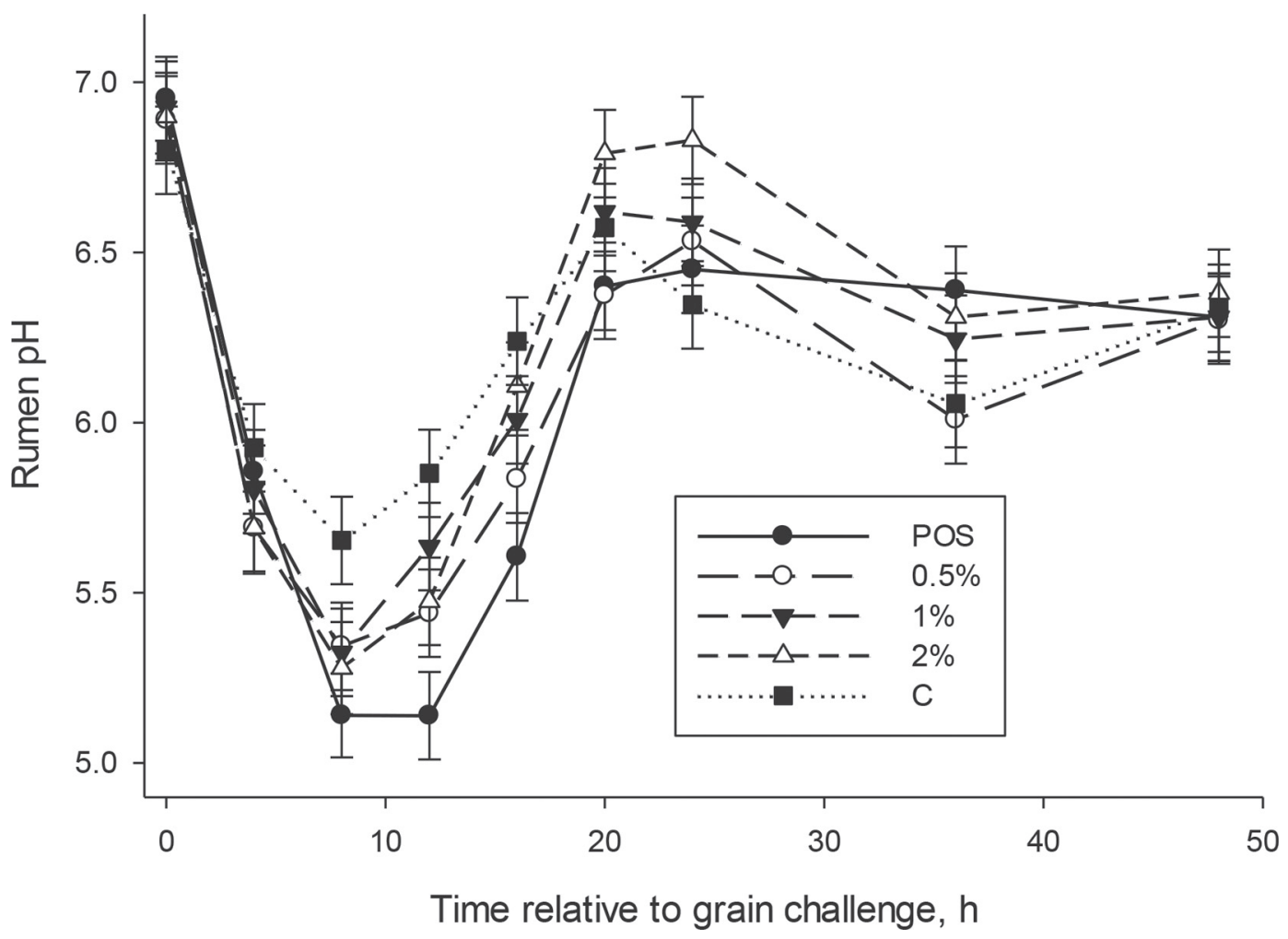

Figure 2. Least squares means $\pm \mathrm{SE}$ for rumen $\mathrm{pH}$ response to a grain challenge $(0 \mathrm{~h})$ for cows in positive control with no clay $(\mathrm{POS}), 0.5$, 1 , or $2 \%$ clay, and negative control $(\mathrm{C})$ treatments from 0 to $48 \mathrm{~h}$ (time points) relative to a grain challenge. Treatment: $P=0.003$; contrast 1 : $P=0.02$; contrast $2: P=0.001$; linear treatment effect: $P=0.53$; time point: $P<0.0001$; treatment $\times$ time point: $P=0.01$.

cows fed C and cows fed POS. Cows fed clay $(0.5,1$, or $2 \%)$ had higher $(P=0.05)$ fecal $\mathrm{pH}$ than cows fed POS.

\section{Health and Activity}

We observed no differences for rectal temperature, general appearance, or fecal score among treatments $(P>0.10)$. Heart rate tended $(P=0.10)$ to be higher for cows fed POS than for cows fed C. Respiratory rate $[($ mean $\pm \mathrm{SE}) 37.0 \pm 1.1$ breaths $/ \mathrm{min}]$ was higher $(P=$ 0.02 ) for cows fed clay (contrast 2) then cows fed POS $(34.1 \pm 1.7)$. Table 5 is an overview of the activity log of all cows throughout the trial. Cows fed clay tended to have less lying time $(P=0.09)$, more standing bouts $(P=0.09)$, and higher total standing time $(P=0.09)$ than cows fed POS. We observed a tendency for a quadratic treatment effect for standing bouts $(P=0.08)$ and standing time $(P=0.07)$.

\section{DISCUSSION}

The aims of this study were to determine the effects of a clay product after a grain challenge on ruminal, blood, and fecal $\mathrm{pH}$, and on milk composition, in mid- lactation Holstein cows; and to determine the most appropriate clay concentration to be used in the diet of dairy cows. We postulated that clay administration in different concentrations would alleviate the effects of a grain challenge and might affect the rumen or intestinal environment or modulate the acid-base metabolism, thereby affecting DMI, nutrient supply, metabolic responses, and performance in Holstein cows.

Cows in the present study encountered SARA when receiving a grain challenge (Gozho et al., 2005). Cows fed $\mathrm{C}$ had less area under the curve below rumen $\mathrm{pH}$ 5.6. These results were expected, because cows fed POS took longer to adjust their rumen environment to the normal $\mathrm{pH}$ range compared with cows fed $\mathrm{C}$ (Figure 2 ). Others have also been successful in reducing rumen pH after a grain challenge (Krause and Oetzel, 2005; Kmicikewycz and Heinrichs, 2014). Stage of lactation (DIM) seems not to have interfered with the effectiveness of the grain challenge. In the present study, cows were in a later stage of lactation than previous experiments. The association of SARA with DMI depression, milk yield depression, reduced feed efficiency, rumenitis, diarrhea, laminitis, inflammation, liver abscesses, and high culling and death rates in dairy cattle has 


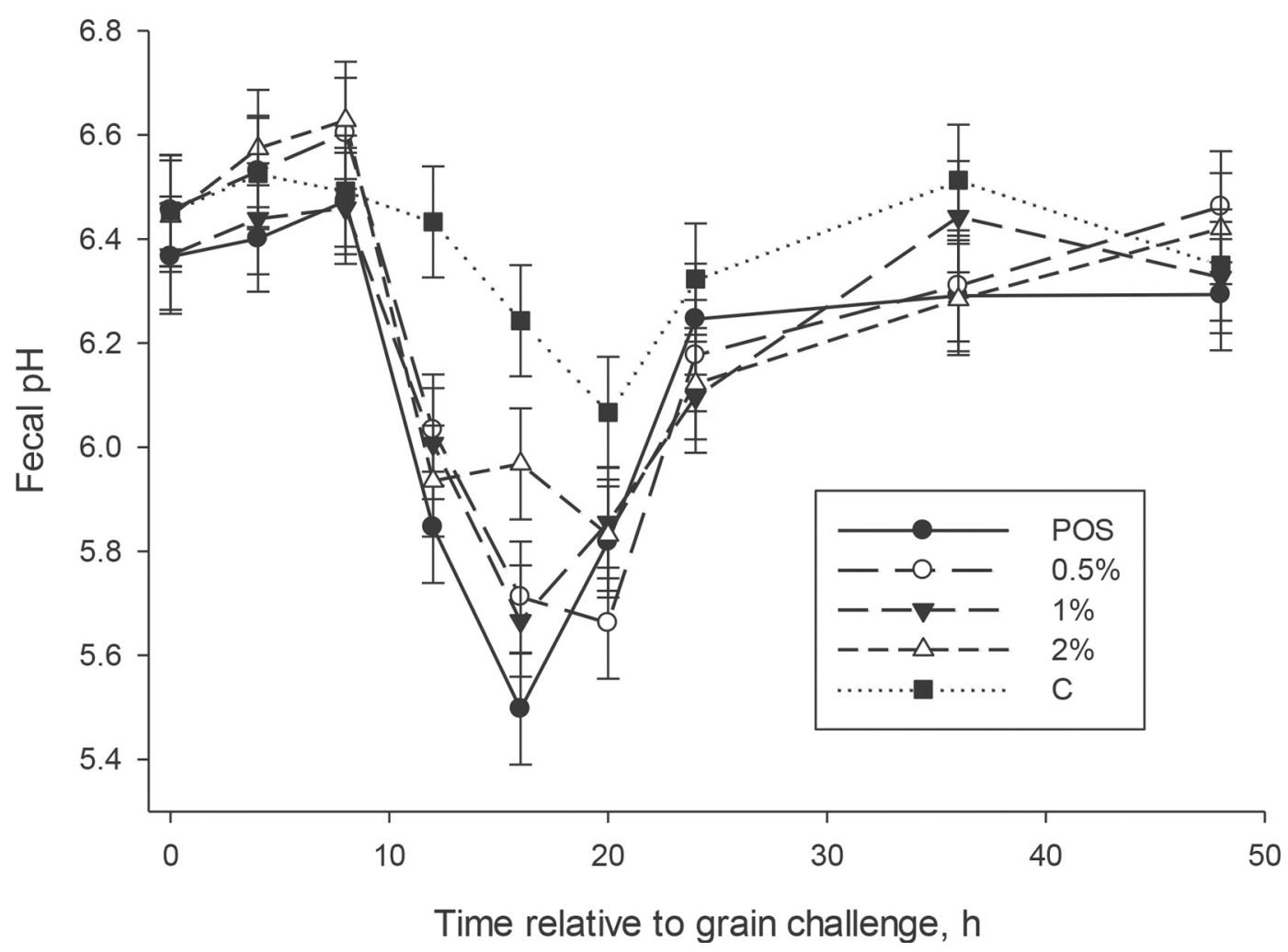

Figure 3. Least squares means $\pm \mathrm{SE}$ for fecal $\mathrm{pH}$ response to a grain challenge $(0 \mathrm{~h})$ for cows in positive control with no clay (POS), $0.5,1$, or $2 \%$ clay, and negative control $(\mathrm{C})$ treatments from 0 to $48 \mathrm{~h}$ (time points) relative to a grain challenge. Treatment: $P<0.01 ;$ contrast $1: P=$ 0.05; contrast 2: $P=0.06$; linear treatment effect: $P=0.72$; time point: $P<0.0001$; treatment $\times$ time point: $P=0.10$.

been extensively reported (Kleen et al., 2003; Al-Zahal et al., 2007; Kmicikewycz and Heinrichs, 2014). In the present study, cows that received the grain challenge had lower DMI than cows that did not receive the grain challenge (contrast 1; Table 3 ).

In the meta-analysis by $\mathrm{Hu}$ and Murphy (2005), rumen $\mathrm{pH}$ increased when buffered diets were used compared with unbuffered diets. The higher contents of magnesium and aluminum silicate may have contributed to the buffering capacity of the clay in the present study. Clays have been shown to work as alkalinizers and have great capacity for $\mathrm{H}^{+}$exchange at different $\mathrm{pH}$ ranges (Yong et al., 1990). The authors reported that illite clay (a type of clay with high concentrations of magnesium and aluminum silicate) had the best buffer capacity in the $\mathrm{pH}$ range from 4.5 to 6 , similar to the rumen $\mathrm{pH}$ range. Additionally, $\mathrm{MgO}$ when used as a buffer, may increase ruminal outflow, increasing the acetate:propionate ratio and improving milk fat tests (Davis, 1979).

Earlier reports from Rindsig et al. (1969) concluded that cows fed clay at $5 \%$ (dietary DMI) had increased acetate and decreased propionate in the rumen, leading to significant increases in milk fat percentage. In our study, a positive linear effect of treatment on rumen $\mathrm{pH}$ indicated that clay at $2 \%$ was most efficient in buffering rumen $\mathrm{pH}$ and reducing the time spent below rumen pH 5.6 after a grain challenge. Greater concentrations of clay may have allowed for greater buffering capacity.

Clay's mode of action is commonly associated with its ion-exchanging capacity (Yong et al., 1990). For instance, clay materials are often used as backfill or buffer materials for radioactive waste disposal sites because of their ion-exchange properties, low permeability, and easy workability (Kumar and Jain, 2013). Hu and Murphy (2005) reported in a meta-analysis that buffers used in diets decreased molar proportions of propionate, which in turn increased the acetate:propionate ratio. Cruywagen et al. (2015) used buffered diets and reported a positive influence on milk fat as acetate was increased in the rumen.

Because clay buffers cause a shift in microbial population to favor acetate in the rumen, leading to an increase in milk fat, it can be hypothesized that the clay product used in the present study worked the same way (Rindsig et al., 1969; Ghorbani et al., 1989; 
Table 5. Least squares means and associated SEM for lying and standing behavior for cows in positive control with no clay (POS), 0.5, 1 , or $2 \%$ clay, and negative control (C) treatments

\begin{tabular}{|c|c|c|c|c|c|c|c|c|c|c|}
\hline \multirow{2}{*}{ Item } & \multicolumn{5}{|c|}{ Treatment $(\text { Trt })^{1}$} & \multirow{2}{*}{ SEM } & \multicolumn{4}{|c|}{$P$-value ${ }^{2}$} \\
\hline & POS & $0.5 \%$ & $1 \%$ & $2 \%$ & $\mathrm{C}$ & & \multicolumn{2}{|c|}{ Contrasts } & \multicolumn{2}{|c|}{ Trt } \\
\hline Lying bouts, no. $/ 24 \mathrm{~h}$ & 24.2 & 21.0 & 23.4 & 23.62 & 24.06 & 5.37 & 0.96 & 0.49 & 0.88 & 0.49 \\
\hline Lying duration, min & 50.6 & 55.7 & 51.6 & 49.84 & 52.18 & 5.59 & 0.76 & 0.69 & 0.65 & 0.48 \\
\hline Lying time, $\min$ & 821.5 & 750.3 & 785.5 & 763.5 & 787.2 & 37.8 & 0.35 & 0.09 & 0.29 & 0.29 \\
\hline Standing time, min & 657.6 & 725.4 & 700.4 & 681.7 & 663.8 & 39.5 & 0.84 & 0.09 & 0.83 & 0.07 \\
\hline
\end{tabular}

${ }^{1}$ Dietary treatments were positive control [POS, without clay $(0 \%)$ and with grain challenge], $0.5 \%$ clay $(0.5 \%$ of the dietary DMI as clay in a top dress), $1 \%$ clay ( $1 \%$ of the dietary DMI as clay in a top dress), $2 \%$ clay ( $2 \%$ of the dietary DMI as clay in a top dress), and negative control (C, without clay and no grain challenge). Top dress vehicle was $500 \mathrm{~g}$ of ground corn. Grain challenge $=20 \%$ of the average of the DMI of the last $3 \mathrm{~d}$ before the challenge as finely ground wheat.

${ }^{2}$ Contrasts: $1=\operatorname{POS}(0 \%)$ compared with C; $2=\operatorname{POS}(0 \%)$ compared with the average of the 3 treatments $(0.5,1$, or $2 \%)$. Linear and quadratic effects of treatments POS $(0 \%), 0.5,1$, and $2 \%$.

Cruywagen et al., 2015). Although VFA were not the main objective of the study, milk fat was significantly increased for cows that received clay during a grain challenge. In addition to increases in milk fat, others have found increases in milk protein yield when cows were fed buffered diets. Cows from 246 to 308 DIM that were fed either $1 \mathrm{~kg}$ or $1 \%$ sodium sesquicarbonate had increased milk protein yield, but not cows earlier in their lactation (Tucker et al., 1994; Clark et al., 2009).

$\mathrm{Hu}$ and Murphy (2005) reported that, with corn silage-based diets, cows ate more when fed sodium bicarbonate, and if corn silage was not the main forage,

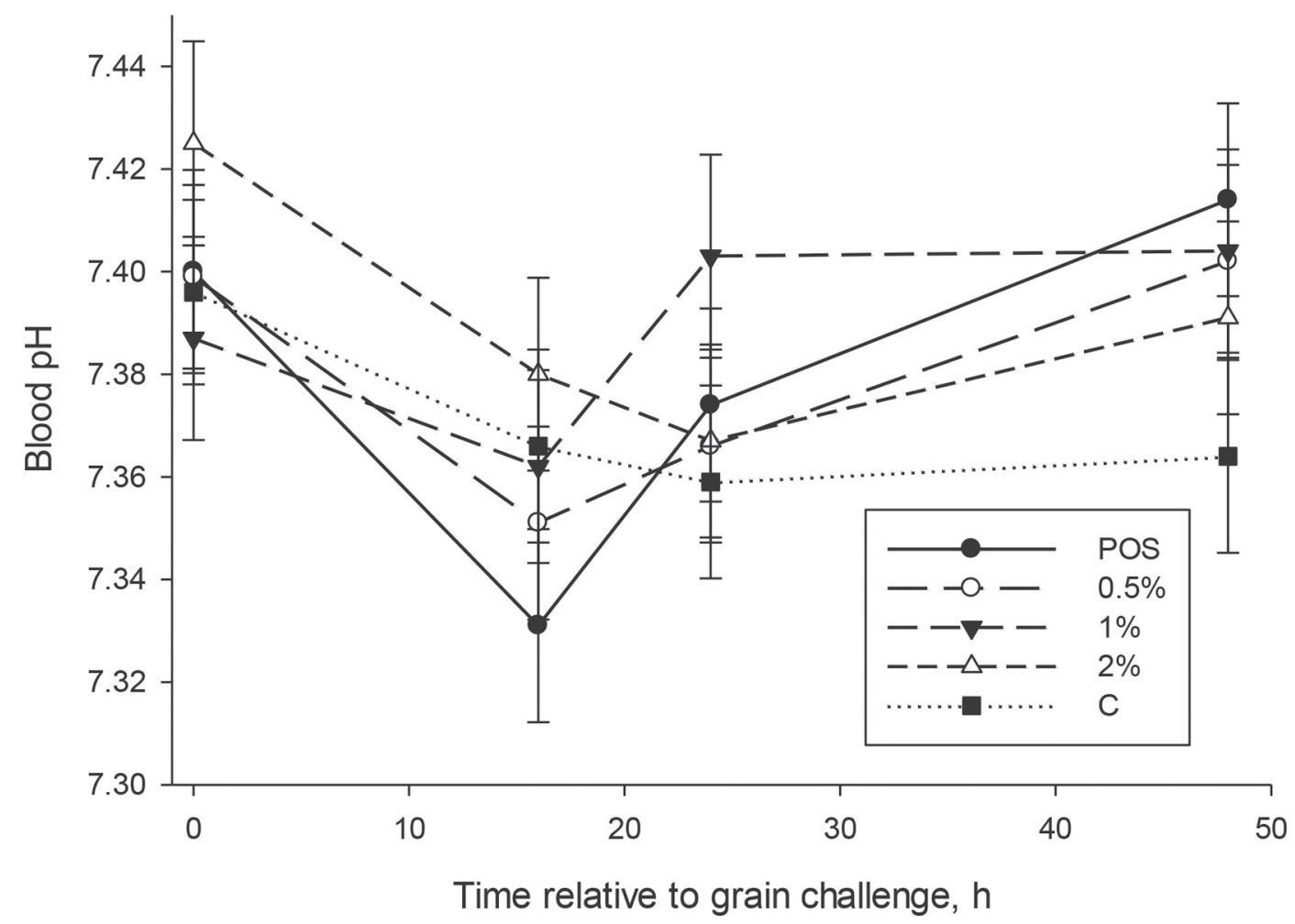

Figure 4. Least squares means $\pm \mathrm{SE}$ for blood $\mathrm{pH}$ response to a grain challenge $(0 \mathrm{~h})$ for cows in positive control with no clay (POS), 0.5 , 1 , or $2 \%$ clay, and negative control $(\mathrm{C})$ treatments from 0 to $48 \mathrm{~h}$ (time points) relative to a grain challenge. Treatment: $P=0.52 ;$ contrast 1 : $P=0.54$; contrast $2: P=0.32$; linear treatment effect: $P=0.88$; time point: $P=0.001$; treatment $\times$ time point: $P=0.57$. 
sodium bicarbonate had no effect on DMI. Others have found similar results, in which buffers had little to no effect on milk production or DMI when the cow's diet was not composed primarily of corn silage (Rearte et al., 1984; Kairenius et al., 2015). Ehrlich and Davison (1997) reported a decrease in DMI when cows were fed $4 \%$ sodium bentonite; however, these cows were fed bentonite mixed with sorghum grain not mixed in with the TMR, which would explain the decrease. The present study had no effect on DMI when fed clay, but cows fed clay did have increased milk yield compared with POS. Cruywagen et al. (2015) found an increase in milk yield for cows fed a mixture of $0.8 \%$ sodium bicarbonate and $0.35 \%$ limestone. Cows fed clay in the present study tended to increase milk yield and milk fat without changing DMI, ultimately leading to an increase in $3.5 \%$ FCM and ECM. These effects may have happened in response to the buffering effects discussed above.

Fecal $\mathrm{pH}$ continues to be under-studied by researchers. In 1980, fecal $\mathrm{pH}$ was reported to increase when cows were fed a combination of $1.5 \%$ sodium bicarbonate and $0.8 \%$ magnesium oxide (Erdman et al., 1980). Results from the present study showed a similar increase in fecal pH. Enemark (2008) reported that fecal $\mathrm{pH}$ is not normally related to ruminal $\mathrm{pH}$ unless starch can bypass the rumen and result in hindgut fermentation. If enough carbohydrates were to bypass the rumen and reach the large intestine, cows would experience hindgut acidosis, in which the fecal consistency could change to frothy with mucin casts (Gressley et al., 2011). We found no significant differences in fecal consistency (score) in the present study; however, Li et al. (2012) reported that fecal $\mathrm{pH}$ decreased when cows experienced SARA.

In the present study, fecal $\mathrm{pH}$ was significantly higher for cows fed clay during a grain challenge. The addition of clay might have caused changes in postruminal fermentation because of reduced outflow of fermentable carbohydrates from the rumen, or binding of fluid in the intestinal lumen with high osmolality (Oetzel, 2000). On the other hand, Luan et al. (2016) conducted a similar study but found no differences in fecal $\mathrm{pH}$. This could be explained by the modest reduction in rumen $\mathrm{pH}$ in that experiment. Fecal $\mathrm{pH}$ and rumen $\mathrm{pH}$ patterns in the present study were similar but showed a lag time (Figures 2 and 3). This delay may have been related to the amount of carbohydrates passing the rumen, even though fecal appearances had no physical characteristics known for hindgut acidosis (Plaizier et al., 2008).

Blood gas measurements showed that cow physiology can maintain blood $\mathrm{pH}$ and its components at constant levels (Dominiczak and Szczepanska-Konkel, 2014). In the present study, cows fed clay had blood $\mathrm{pH}$ values closer to the reported normal range of blood $\mathrm{pH}$, at 7.4 (Bigner et al., 1997). Although we observed no significant differences among treatments, each treatment was different at different time points. From Figure 4, the cows fed POS reached the lowest blood $\mathrm{pH}$ (7.33) of all treatment groups $12 \mathrm{~h}$ following grain challenge. The diet containing $1 \%$ clay reached a blood $\mathrm{pH}$ of 7.36 at the same time point and regained normal values by 24 h. Bigner et al. (1997) conducted a study in which 500 $\mathrm{g}$ of sodium bicarbonate and $343 \mathrm{~g}$ of sodium propionate oral treatments raised blood $\mathrm{pH}$. An association between blood $\mathrm{pH}$ and $\mathrm{HCO}_{3}$ has been noted, but in the present study, we found no link between blood $\mathrm{pH}$ and clay administration. We observed a tendency for a linear increase in $\mathrm{O}_{2}$ saturation percentage (Table 4) as clay was included in the diet. According to Karnland et al. (2006), a fraction of extractable iron oxides derived from some clay structures, upwards of $3.5 \%$, were extracted from montmorillonite samples found in Germany, Czech Republic, and India. Therefore, one could hypothesize that increased $\mathrm{O}_{2}$ saturation could be derived from the increased clay inclusion in the diet. However, the simple fact that cows had a higher respiration rate when fed clay through the challenge phase could have explained the linear effect on blood $\mathrm{O}_{2}$ saturation.

Cows that received clay tended to spend less time lying down and more total time standing, as well as having an increased number of standing bouts. DeVries et al. (2009) correlated standing time and lying activity with eating behavior. As the risk of acidosis becomes more prominent, the frequency of meals decreases and the duration of mealtime increases. In the present study, we observed no differences in DMI, but we did not measure mealtime.

\section{CONCLUSIONS}

Feeding clay helped alleviate the effect of a grain challenge on the rumen environment and ultimately affected the performance of Holstein cows. Cows fed $0.5,1$, or $2 \%$ clay tended to yield more milk and did yield more 3.5\% FCM and ECM than cows fed POS. A positive linear treatment effect on rumen $\mathrm{pH}$ indicated that clay at $2 \%$ was most efficient in buffering rumen $\mathrm{pH}$ and reducing the time spent below rumen $\mathrm{pH} 5.6$ after a grain challenge. Production and physiological parameters suggest that clay may be an alternative buffer in diets for dairy cows.

\section{ACKNOWLEDGMENTS}

This project was partially supported by the UMG Minerals Group (Kiev, Ukraine). The authors are 
grateful for the University of Illinois researchers, veterinarians, and the Dairy Research Unit staff involved in collection of the data.

\section{REFERENCES}

Adamis, Z., and R. B. Williams. 2005. Bentonite, Kaolin, and Selected Clay Minerals. Environmental Health Criteria 231. World Health Organization, Geneva, Switzerland.

AlZahal, O., E. Kebreab, J. France, and B. W. McBride. 2007. A mathematical approach to predicting biological values from rumen pH measurements. J. Dairy Sci. 90:3777-3785.

AOAC International. 1995a. AOAC official method 934.01. Moisture in animal feed. Pages 23-26 in Official Methods of Analysis. 16th ed. Vol. 2. AOAC International, Arlington, VA.

AOAC International. 1995b. AOAC official method 972.16. Fat, lactose, protein, and solids in milk. Mid-infrared spectroscopic method. Pages 23-26 in Official Methods of Analysis. 16th ed. Vol. 2. AOAC International, Arlington, VA.

Ashwood, E. R., G. Kost, and M. Kenny. 1983. Temperature correction of blood-gas $\mathrm{pH}$ measurements. Clin. Chem. 29:1877-1885.

Bigner, D. R., J. P. Goff, M. A. Faust, H. D. Tyler, and R. L. Horst. 1997. Comparison of oral sodium compounds for the correction of acidosis. J. Dairy Sci. 80:2162-2166.

Buckman, H. O., and N. C. Brady. 1969. The Nature and Properties of Soils. 7th ed. MacMillan, New York, NY.

Cardoso, F. C., W. Sears, S. J. LeBlanc, and J. K. Drackley. 2011. Technical note: Comparison of 3 methods for analyzing areas under the curve for glucose and nonesterified fatty acids concentrations following epinephrine challenge in dairy cows. J. Dairy Sci. 94:6111-6115.

Clark, J. H., R. A. Christensen, H. G. Bateman II, and K. R. Cummings. 2009. Effects of sodium sesquicarbonate on dry matter intake and production of milk and milk components by Holstein cows. J. Dairy Sci. 92:3354-3363.

Cruywagen, C. W., S. Taylor, M. M. Beya, and T. Calitz. 2015. The effect of buffering dairy cow diets with limestone, calcareous marine algae, or sodium bicarbonate on ruminal $\mathrm{pH}$ profiles, production responses, and rumen fermentation. J. Dairy Sci. 98:5506-5514.

Davis, C. L. 1979. The use of buffers in the rations of lactating dairy cows. Pages 51-54 in Regulation of Acid-Base Balance. W. H. Hale and P. Meinhardt, ed. Church and Dwight Inc., Piscataway, NJ.

DeVries, T. J., K. A. Beauchemin, F. Dohme, and K. S. SchwartzkopfGenswein. 2009. Repeated ruminal acidosis challenges in lactating dairy cows at high and low risk for developing acidosis: Feeding, ruminating, and lying behavior. J. Dairy Sci. 92:5067-5078.

Dominiczak, M. H., and M. Szczepanska-Konkel. 2014. Regulation of hydrogen ion concentration (acid-base balance). Pages 332-342 in Medical Biochemistry. 4th ed. Elsevier Ltd., Oxford, UK.

Duffield, T., J. C. Plaizier, A. Fairfield, R. Bagg, G. Vessie, P. Dick, J. Wilson, J. Aramini, and B. McBride. 2004. Comparison of techniques for measurement of rumen $\mathrm{pH}$ in lactating dairy cows. J. Dairy Sci. 87:59-66.

Eastridge, M. L. 2006. Major advances in applied dairy cattle nutrition. J. Dairy Sci. 89:1311-1323.

Ehrlich, T. K., and T. M. Davison. 1997. Adding bentonite to sorghum grain-based supplements has no effect on cow milk production. Aust. J. Exp. Agric. 37:505-508.

Enemark, J. M. D. 2008. The monitoring, prevention and treatment of sub-acute ruminal acidosis (SARA): A review. Vet. J. 176:32-43.

Erdman, R. A., R. W. Hemken, and L. S. Bull. 1980. Effect of dietary calcium and sodium on potassium requirement for lactating dairy cows. J. Dairy Sci. 63:538-544.

Everson, R. A., N. A. Jorgensen, and G. P. Barrington. 1971. Effect of bentonite, nitrogen source and stage of maturity on nitrogen redistribution in corn silage. J. Dairy Sci. 54:1482-1490.

Ferguson, J. D., D. T. Galligan, and N. Thomsen. 1994. Principal descriptors of body condition score in Holstein cows. J. Dairy Sci. $77: 2695-2703$.
Ghorbani, G. R., J. A. Jackson, and R. W. Hemken. 1989. Effects of sodium bicarbonate and sodium sesquicarbonate on animal performance, ruminal metabolism, and systemic acid-base status. J. Dairy Sci. 72:2039-2045.

Gozho, G. N., J. C. Plaizier, D. O. Krause, A. D. Kennedy, and K. M. Wittenberg. 2005. Subacute ruminal acidosis induces ruminal lipopolysaccharide endotoxin release and triggers an inflammatory response. J. Dairy Sci. 88:1399-1403.

Gressley, T. F., M. B. Hall, and L. E. Armentano. 2011. Ruminant nutrition symposium: Productivity, digestion, and health responses to hindgut acidosis in ruminants. J. Anim. Sci. 89:1120-1130.

Hu, W. P., and M. R. Murphy. 2005. Statistical evaluation of earlyand mid-lactation dairy cow responses to dietary sodium bicarbonate addition. Anim. Feed Sci. Technol. 119:43-54.

Ireland-Perry, R. L., and C. C. Stallings. 1993. Fecal consistency as related to dietary composition in lactating Holstein cows. J. Dairy Sci. 76:1074-1082.

Kairenius, P., A. Arola, H. Leskinen, V. Toivonen, S. Ahvenjarvi, A. Vanhatalo, P. Huhtanen, T. Hurme, J. M. Griinari, and K. J. Shingfield. 2015. Dietary fish oil supplements depress milk fat yield and alter milk fatty acid composition in lactating cows fed grass silage-based diets. J. Dairy Sci. 98:5653-5671.

Karnland, O., S. Olsson, and U. Nilsson. 2006. Mineralogy and sealing properties of various bentonites and smectite-rich clay materials. SKB Internal Report TR-06-30. Clay Technology, Stockholm, Sweden.

Khorasani, G. R., and J. J. Kennelly. 2001. Influence of carbohydrate source and buffer on rumen fermentation characteristics, milk yield, and milk composition in late-lactation Holstein cows. J. Dairy Sci. 84:1707-1716.

Kleen, J. L., G. A. Hooijer, J. Rehage, and J. P. T. M. Noordhuizen. 2003. Subacute ruminal acidosis (SARA): A review. J. Vet. Med. A Physiol. Pathol. Clin. Med. 50:406-414.

Kmicikewycz, A. D., and A. J. Heinrichs. 2014. Feeding lactating dairy cattle long hay separate from the total mixed ration can maintain dry matter intake during incidents of low rumen $\mathrm{pH}$. J. Dairy Sci. 97:7175-7184.

Kononoff, P. J., A. J. Heinrichs, and D. R. Buckmaster. 2003. Modification of the Penn State Forage and total mixed ration particle separator and the effects of moisture content on its measurements. J. Dairy Sci. 86:1858-1863.

Krause, K. M., D. V. Dhuyvetter, and G. R. Oetzel. 2009. Effect of a low-moisture buffer block on ruminal $\mathrm{pH}$ in lactating dairy cattle induced with subacute ruminal acidosis. J. Dairy Sci. 92:352-364.

Krause, K. M., and G. R. Oetzel. 2005. Inducing subacute ruminal acidosis in lactating dairy cows. J. Dairy Sci. 88:3633-3639.

Krause, K. M., and G. R. Oetzel. 2006. Understanding and preventing subacute ruminal acidosis in dairy herds: A review. Anim. Feed Sci. Technol. 126:215-236.

Kumar, S., and S. Jain. 2013. Review: History, introduction, and kinetics of ion exchange materials. J. Chem. 2013:1-13.

Li, S., E. Khafipour, D. O. Krause, A. Kroeker, J. C. RodriguezLecompte, G. N. Gozho, and J. C. Plaizier. 2012. Effects of subacute ruminal acidosis challenges on fermentation and endotoxins in the rumen and hindgut of dairy cows. J. Dairy Sci. 95:294-303.

Littell, R. C., W. W. Stroup, and R. J. Freund. 2002. SAS for Linear Models. 4th ed. SAS Institute Inc., Cary, NC.

Luan, S., K. Cowles, M. R. Murphy, and F. C. Cardoso. 2016. Effect of a grain challenge on ruminal, urine, and fecal $\mathrm{pH}$, apparent total tract starch digestibility, and milk composition of Holstein and Jersey cows. J. Dairy Sci. 99:2190-2200.

NRC. 2001. Nutrient Requirements of Dairy Cattle. 7th rev. ed. Natl. Acad. Press, Washington, DC.

Oetzel, G. R. 2000. Clinical aspects of ruminal acidosis in dairy cattle. Pages 46-53 in Proc. 33rd Annual Mtg. Am. Assoc. Bovine Pract., Rapid City, SD. Am. Assoc. Bovine Pract., Auburn, AL.

Plaizier, J. C., D. O. Krause, G. N. Gozho, and B. W. McBride. 2008. Subacute ruminal acidosis in dairy cows: The physiological causes, incidence and consequences. Vet. J. 176:21-31. 
Rearte, D. H., E. M. Kesler, and W. C. Stringer. 1984. Forage growth and performance of grazing dairy cows fed concentrates with or without sodium bicarbonate. J. Dairy Sci. 67:2914-2921.

Rindsig, R. B., L. H. Schultz, and G. E. Shook. 1969. Effects of the addition of bentonite to high-grain dairy rations which depress milk fat percentage. J. Dairy Sci. 52:1770-1775.

Shaver, R. D., L. E. Armentano, and J. W. Crowley. 2000. Dietary Buffers for Dairy Cattle. Cooperative Extension Publications, Madison, WI.

Trckova, M., L. Matlova, L. Dvorska, and I. Pavlik. 2004. Kaolin, bentonite, and zeolites as feed supplements for animals: Health advantages and risks. Vet. Med. Czech. 49:389-399.

Tucker, W. B., I. S. Shin, J. F. Hogue, M. Aslam, G. D. Adams, M T. Van Koevering, R. K. Vernon, and K. R. Cummings. 1994. Natural sodium sesquicarbonate fed for an entire lactation: Influ- ence on performance and acid-base status of dairy cows. J. Dairy Sci. 77:3111-3117.

Weimer, P. J., D. M. Stevenson, and D. R. Mertens. 2010. Shifts in bacterial community composition in the rumen of lactating dairy cows under milk fat-depressing conditions. J. Dairy Sci. 93:265278.

Wester, L. 2002. Offering sodium bentonite and sodium bicarbonate free-choice to lactating dairy cattle. MS Thesis. Virginia Polytechnic Institute and State Univ., Blacksburg, VA.

Yang, W. Z., K. A. Beauchemin, and L. M. Rode. 2001. Effects of grain processing, forage to concentrate ratio, and forage particle size on rumen $\mathrm{pH}$ and digestion by dairy cows. J. Dairy Sci. 84:2203-2216.

Yong, R. N., D. P. Warkentin, Y. Phadungchewit, and R. Galvez. 1990. Buffer capacity and lead retention in some clay materials. Water Air Soil Pollut. 53:53-67. 